\title{
Colonial Railways and Conflict Resolution Between Portugal and the United Kingdom in Africa (c. 1880-early 1900s)
}

\section{Hugo Silveira Pereira}

Centro Interuniversitário de História das Ciências e da Tecnologia (CIUHCT), Faculdade de Ciências e Tecnologia, Universidade NOVA de Lisboa

Institute of Railway Studies, University of York hugojose.pereira@gmail.com

Abstract: In the 1870s, Portugal transferred the public works program it was undertaking on the mainland - in which railways played a decisive role - to its African colonies of Angola and Mozambique. In this strategy, the United Kingdom was an obvious partner, given the historical connection between both nations and the geographical proximity between the colonies each country had in Africa. However, British and Portuguese imperial agendas could easily clash, as both London and Lisbon coveted the same areas of Africa. Hence, the initial and apparent cooperation rapidly evolved to a situation of conflict. In this paper, I aim to analyse three instances of dispute between Portugal and Britain about colonial railways in Angola and Mozambique. I will use the methodological tools of conflict resolution analysis in a historical perspective and the concept of track-two diplomacy within the framework of technodiplomacy.

Keywords: technodiplomacy; track-two diplomacy; railways; scramble for Africa; Angola; Mozambique 


\section{Introduction and methodology}

In the mid-1870s, Portugal presented the first proposals to build railways in its overseas territories of Africa (Angola and Mozambique), ${ }^{1}$ and thus apply in the colonies the development program that it had been implementing in the mainland since the 1850s that privileged transnational rail links from strategic hinterlands to Portuguese harbours. ${ }^{2}$ Additionally, it was understood that in order to fulfil this project in Africa, Britain and British capital were privileged partners, given the historical connections between both nations and the geographical proximity of each country's territories in Africa. ${ }^{3}$ Until the 1930s, several thousand miles of tracks were built either by private companies or by the State, and added to the Portuguese railway network in the colonies. $^{4}$

The investment sought two different goals: to tap into the imagined resources of the colonial hinterlands and to cement the Portuguese presence in territories that were coveted by other, more powerful, European nations. ${ }^{5}$ These objectives, however, could clash with the agendas of other countries with similar interests in colonial territories. Moreover, most of the capital required for such investment came from abroad, which could also be a cause for international divergences. All of this could give rise to conflict situations, sometimes directly (between the nations involved), on other occasions indirectly (through informal agents/go-betweens).

\footnotetext{
${ }^{1}$ These included the lines between Luanda and Ambaca (in Angola) and Lourenço Marques (Delagoa Bay, in Mozambique) and Transvaal (in South Africa).

${ }^{2}$ Bruno José Navarro Marçal, "Um império projectado pelo ‘silvo da locomotiva’. O papel da engenharia portuguesa na apropriação do espaço colonial africano. Angola e Moçambique (1869-1930)" (PhD diss., Universidade NOVA de Lisboa, 2016), 115.

${ }^{3}$ Valentim Alexandre, Velho Brasil Novas Africas. Portugal o Império (1808-1975) (Porto: Afrontamento, 2000), 150-151.

${ }^{4}$ Until the 1930s, private companies and the Portuguese State set railroads in the provinces of Benguela, Moçâmedes (Angola), Manica, Sofala, Lourenço Marques, Zambezi, and Moçambique (Mozambique).

${ }^{5}$ These two goals met two myths of the Portuguese imagination of the time about Africa (as defined by Portuguese historian, Valentim Alexandre): the myth of Eldorado (the perception that the colonial hinterland was ripe with resources just waiting to be exploited) and the myth of the sacred heritage (the idea that the overseas territories were tokens of the former glory of Portugal and could never be separated from the motherland). See Valentim Alexandre and Jill Dias, "O Império Africano 18251890," in Nova História da Expansão Portuguesa, eds. Joel Serrão and A. H. de Oliveira Marques, vol. X (Lisbon: Estampa, 1998), 39-48.
}

HoST - Journal of History of Science and Technology 12, pp. 75-105

DOI 10.2478/host-2018-0004 
In this paper I aim to analyse three conflicts between Portuguese and British interests regarding colonial railways in Angola (the Ambaca line) and Mozambique (the Delagoa Bay/Lourenço Marques, and Beira lines) and determine how they were resolved. ${ }^{6}$ Considering that "the list of disciplines that the systematic study of conflict may draw upon is very long - including the full range of the social sciences and the humanities" - I intend to contribute to the debate by combining history of technology and conflict resolution to offer an historical perspective on the resolution of international conflict. The three examples I will analyse in this paper had different inceptions, characteristics, and outcomes, and this was the main reason why I chose them - to test my model in dissimilar situations.

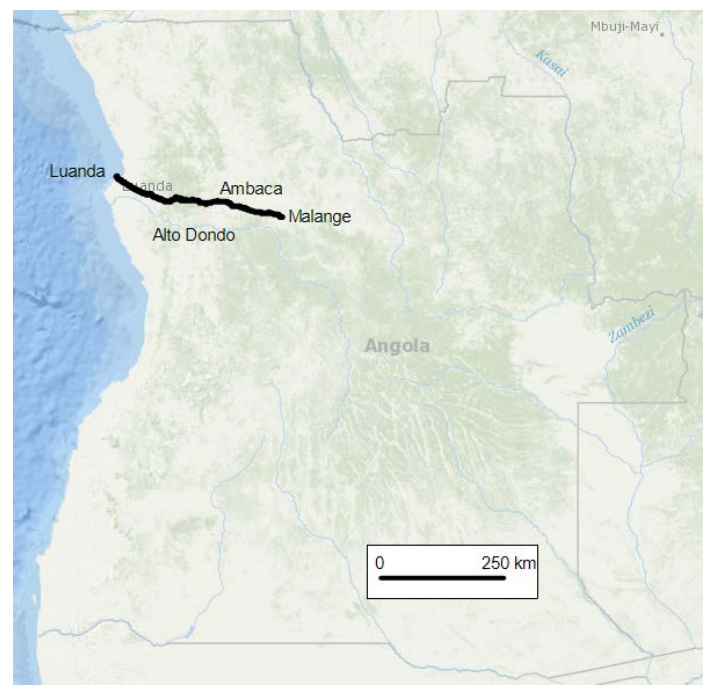

Figure 1 - The Ambaca railway in Angola Source: sharemap.org and own making

\footnotetext{
${ }^{6}$ The conflicts analysed never escalated to an all-out war. They include those between the Portuguese government and: (1) the Portuguese company of the Luanda-Ambaca railway, and its British bondholders (in Angola); (2) the American contractor of the Delagoa Bay railroad and its British financiers; and (3) the British government and Cecil Rhodes in the context of the adjudication of the Beira railway in the aftermath of the British Ultimatum of 1890 and the subsequent 1891 Treaty. Further details about these historical episodes will be provided in the following sections.

${ }^{7}$ James Schellenberg, Conflict Resolution. Theory, Research, and Practice (Berkeley: The University of California Press, 1986), 7 and 28-30. See also Leonard W. Doob, "Series Foreword," in Conflict Resolution. Cross-Cultural Perspectives, eds. Kevin Avruch, Peter W. Black, and Joseph A. Scimecca, IX-X (London: Greenwood, 1991), IX.
}

HoST - Journal of History of Science and Technology 12, pp. 75-105 


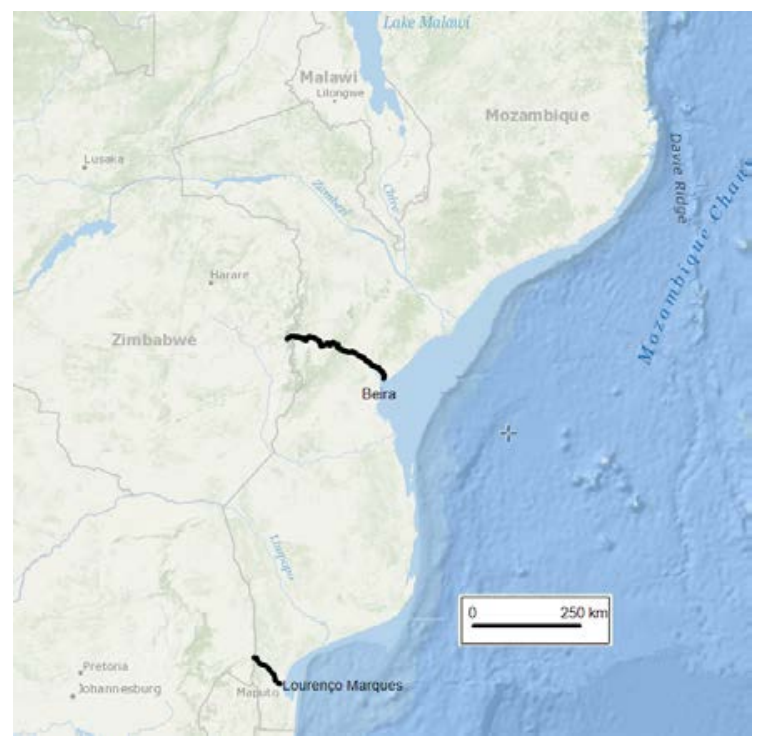

Figure 2 - The Beira and Delagoa Bay/Lourenço Marques railways in Mozambique Source: sharemap.org and own making

I will draw from a very simple notion of conflict: a situation, real or perceived, of opposition, incompatibility of interests/goals, inconsistency of visions, or lack of agreement for a mutual understanding that threatens the needs or interests of the parties involved. Conflict resolution, on the other hand, is the interactive and fluid process, requiring more than a core of knowledge and a set of tools, that looks for a result that might represent an improvement to the arguing parties, and that leads to a new situation where the opposition between parties is reduced, thanks to a conscious settlement of the issues in dispute. ${ }^{8}$

Goncalves identified different stages of that process: beginning of the dispute; early escalation - the issues are not resolved and the conflict increases; deadlock - the opposing sides are unable to reach an understanding; looking for a way out - the parts can no longer tolerate the consequences of the conflict and they try to reach an

${ }^{8}$ Marcus Goncalves, Conflict Resolution. Concepts and Practice (New York: ASME, 2008), 3 and 6-7. Thomas L. Saaty and Joyce M. Alexander, Conflict Resolution. The Analytic Hierarchy Approach (London: Praeger, 1989), 3. Schellenberg, Conflict Resolution, 8-9.

HoST - Journal of History of Science and Technology 12, pp. 75-105

DOI 10.2478/host-2018-0004 
agreement; and working together - to implement that agreement. ${ }^{9}$ Depending on the nature and evolution of the conflict some of these stages might be skipped.

The final solution for a conflict might be achieved through negotiation between parties, mediation through a third party, sentence by independent referees in an arbitration process, or plain brute force. ${ }^{10}$ Hence, even if there is a solution for a conflict, it does not imply that all parties win or that all parties are happy with the final outcome. In some cases, there might be winners and losers. In the same respect, I do not mean to affirm that all conflicts are solvable. Some might not have a solution, but they can be manageable. ${ }^{11}$

Determining the nature of the conflict is the first step in the analysis. ${ }^{12} \mathrm{I}$ argue that the conflicts between Portugal and Britain were set at an international/diplomatic level and were deeply concerned with the control of colonial railways - considering that railways were a powerful tool of imperialism ${ }^{13}$ and of territorial appropriation, ${ }^{14}$ they could determine who had the practical rule over the disputed territories of Angola and Mozambique.

Therefore, I will use the concept of technodiplomacy and claim that the resolution of the conflict occurred at a technodiplomatic level. Schweitzer originally defined technodiplomacy as "the art and practice of conducting negotiations between countries

\footnotetext{
${ }^{9}$ Goncalves, Conflict Resolution, 66-70.

${ }^{10}$ Joseph V. Montville, "The Arrow and the Olive Branch. A Case for Track Two Diplomacy," in Conflict Resolution: Track Two Diplomacy, eds. John W. McDonald Jr and Diane B. Bendahmane, 5-20 (Washington: Foreign Service Institute, 1987), 19. Saaty and Alexander, Conflict Resolution, 3. Schellenberg, Conflict Resolution, 13, 133-134, 153-154, 171-172, 192 and 204-205.

${ }^{11}$ Saaty and Alexander, Conflict Resolution, 15. Schellenberg, Conflict Resolution, 213.

${ }^{12}$ Schellenberg, Conflict Resolution, 12 and 97. It is easily imaginable that these conflicts had ramifications in internal politics (of both Portugal and Britain). For the purposes of this paper I will leave these implications out of my analysis.

${ }^{13}$ Daniel R. Headrick, The Tools of Empire. Technology and European Imperialism in the Nineteenth Century (Oxford: Oxford University Press, 1981), 14.

${ }^{14}$ Ben Marsden and Crosbie Smith, Engineering Empires. A Cultural History of Technology in NineteenthCentury Britain (London: Palgrave MacMillan, 2005), 167. Mattias Kärrholm, Retailising Space. Architecture, Retail and the Territorialisation of Public Space (Burlington: Ashgate, 2012), 16 and 137138.
}

HoST - Journal of History of Science and Technology 12, pp. 75-105

DOI 10.2478/host-2018-0004 
with conflicting technological interests." ${ }^{15}$ In a recent study I broadened that definition to "the use of technology to impose such technological interests or an overall national agenda over a foreign country" ${ }^{16}$ and indeed, railways in Africa were used to do so (see below). Schweitzer's framework also highlights that in technodiplomacy, negotiations are conducted to avoid hostilities and "in the direction of peace and not war." I also contend that negotiation always sought a peaceful settlement and war was an outcome that was not desired by any of the parties involved. ${ }^{17}$

Furthermore, in the analysis of the (techno-)diplomatic intricacies of the negotiations, I willhighlighttheroleofthosenon-governmentalagents thatactunofficiallyasgo-betweens for different governments - or what it is commonly known as track-two diplomacy. ${ }^{18}$ In this regard I will also bear in mind to what extent these agents possessed what Lubinski calls the "advantage of outsiderness," which is that feature that allowed historical actors to act as political outsiders in a given context to gain political and economic advantages. ${ }^{19}$

\footnotetext{
${ }^{15}$ Glenn E. Schweitzer, Techno-diplomacy. US-Soviet Confrontations in Science and Technology (London: Plenum, 1989), V. Schweitzer is not the only author to describe negotiations between parties with different agendas as an art. Goncalves (Conflict Resolution, 66-70) also defines conflict resolution as "an art and a science."

${ }^{16}$ Hugo Silveira Pereira, "The technodiplomacy of Iberian transnational railways in the second half of the nineteenth century," History and Technology 37, no. 2: 175-195, on 177.

${ }^{17}$ See Montville, "The Arrow and the Olive Branch," 19.

${ }^{18}$ John W. McDonald Jr, "Introduction," in Conflict Resolution: Track Two Diplomacy, eds. John W. McDonald Jr and Diane B. Bendahmane, 1-4 (Washington: Foreign Service Institute, 1987). Burton (1987: 72) claims that track-two diplomacy may also be formal and official. Regardless, for the purposes of this paper, I will stick to the notion that track-two diplomats act informally and unofficially. John W. Burton, "Track Two: An Alternative to Power Politics," in Conflict Resolution: Track Two Diplomacy, eds. John W. McDonald Jr and Diane B. Bendahmane, 65-72 (Washington: Foreign Service Institute, 1987), 72.

${ }^{19}$ Christina Lubinski presented this concept at the 2017 Business History Conference in Denver, Colorado (USA). I would like to thank her for allowing me to use it.
} 
This feature is especially important when we remember that usually it was private agents (supported by the metropolitan government) who exerted British informal imperialism..$^{20}$

Moreover, I maintain that the conflicts between Portugal and Britain were not only financial/resource-based, ${ }^{21}$ but were also of an ideological/cultural nature, and they arose from intangible factors, which rendered them more difficult to resolve. ${ }^{22}$ Hence, I will take into consideration not only the political/diplomatic international context, ${ }^{23}$ but also the cultural background of the relationship between Portugal and Britain in Africa. Several authors have highlighted the importance of these cultural and identity issues in conflict resolution in the past. ${ }^{24}$ In the cases at hand, we must bear in mind that conflict resolution processes occurred in the aftermath of two traumatic events for the Portuguese national pride. One was: an ultimatum issued by Britain to Portugal (1890) demanding the removal of Portuguese forces from the areas in Africa between Angola and Mozambique - a diplomatic event that in Portugal reinforced the nationalistic feeling towards the colonies and the overall Portuguese identity; the second trauma was the declaration of a partial default of the Portuguese exchequer in 1892.

Additionally, I say that railways in Africa, besides being an investment and a tool of

${ }^{20}$ John Darwin, “Globalism and Imperialism: the Global Context of British Power, 1830-1960," in Gentlemanly Capitalism, Imperialism and Global History, ed. Shigeru Akita, 43-64 (Houndmills: Palgrave-MacMillan, 2002), 44-52. W. Travis Hanes III, "Railway Politics and Imperialism in Central Africa, 1889-1953," in Railway Imperialism, eds. Clarence B. Davis, Kenneth E. Wilburn Jr, and Ronald E. Robinson, 41-69 (London: Greenwood, 1991), 46-48. Ronald E. Robinson, "Conclusion: Railways and Informal Empire," in Railway Imperialism, eds. Clarence B. Davis, Kenneth E. Wilburn Jr, and Ronald E. Robinson, 175-197 (London: Greenwood, 1991), 189-190.

${ }^{21}$ Money and financial issues also played a relevant role in the processes I analyse in this paper. For the importance of money in the production and use of technoscience see Casper Andersen, Jakob BekThomsen and Peter C. Kjærgaard, "The Money Trail: A New Historiography for Networks, Patronage, and Scientific Careers," Isis 103, no. 2 (2012): 310-315.

${ }^{22}$ Jay Rothman, Resolving Identity-Based Conflict in Nations, Organizations, and Communities (San Francisco: Jossey-Bass, 1997), 10-11 and 16.

${ }^{23}$ Philip D. Stewart, "The Dartmouth Conference: U.S.-U.S.S.R. Relations," in Conflict Resolution: Track Two Diplomacy, eds. John W. McDonald Jr and Diane B. Bendahmane, 21-26 (Washington: Foreign Service Institute, 1987), 25.

${ }^{24}$ Kevin Avruch, "Introduction: Culture and Conflict Resolution," in Conflict Resolution. Cross-Cultural Perspectives, eds. Kevin Avruch, Peter W. Black, and Joseph A. Scimecca, 1-17 (London: Greenwood, 1991), 1-2. Goncalves, Conflict Resolution, 61-64. Schellenberg, Conflict Resolution, 65-66 and 76.

HoST - Journal of History of Science and Technology 12, pp. 75-105

DOI 10.2478/host-2018-0004 
colonization, also possessed a relevant cultural value and were powerful instruments to impose metropolitan national identities in the African colonies. Many studies have underlined the cultural importance of technology and its decisive role in the construction of national identities. ${ }^{25}$ In the same respect, different researchers have also stressed the relevance of the railroad for the construction of identities in sundry contexts. In England, Philip Paynton showed how the railway contributed to the construction of the identity of the rural Englishness. ${ }^{26}$ In Switzerland, the Saint Gotthard tunnel, inaugurated in 1882, was, for generations, "a symbol of the country's independence, defiant and able to defend itself." ${ }^{27}$ Moving to the colonial context, railroads and railway stations acted as instruments of power, pride, and Europeanization of the overseas territories. ${ }^{28}$ Jeremy Foster, in a study about South Africa, also highlights the power of railways (amidst other tools of so-called modernity) to transform and build "the imaginary space of the nation." ${ }^{29}$ Hence, any dispute regarding railways in Africa also involved cultural and identity issues, which, as far as the wrangles were concerned, "simply added fuel to the fire." 30

To analyse these issues, I propose a rather simple and straightforward framework,

\footnotetext{
${ }^{25}$ See David Nye, American Technological Sublime (Cambridge: The MIT Press, 1999) for the American example and Tiago Saraiva, "Inventing the Technological Nation: the Example of Portugal (18511898)," History and Technology 23, no. 3 (2007): 263-273 for a European case-study.

${ }^{26}$ Philip Paynton, "'An English cross-country railway': rural England and the cultural reconstruction of the Somerset and Dorset Railway," Working Papers in Railway Studies 2 (1996): 17-25.

${ }^{27}$ Judith Schueler, "Travelling towards the 'mountain that has borne a state'. The Swiss Gotthard Railways," in Networking Europe. Transnational Infrastructures and the Shaping of Europe, 1850-2000, eds. Erik van der Vleuten and Arne Kaijser, 71-96 (Sagamore Beach: Science History Publications, 2006), 82-87.

${ }^{28}$ Pascal Blanchard and Sandrine Lemaire, eds., Culture coloniale. La France conquise par son Empire (Paris: Autrement, 2003), 23-27. Maria Paula Diogo, “Domesticating the Wilderness': Portuguese Engineering and the Occupation of Africa," in The Quest for a Professional Identity: Engineers between Training and Action, eds. Ana Cardoso de Matos, Maria Paula Diogo, André Grelon, and Irina Gouzévitch, 471-482 (Lisbon: Colibri, 2009). Catherine Hall, Civilising Subjects: Metropole and Colony in the English Imagination 1830-1867 (Chicago: The University of Chicago Press, 2002), 10-14. Ian J. Kerr, "Representation and Representations of the Railways of Colonial and Post-Colonial South Asia," Modern Asian Studies 37, no. 2, 287-326, on 291.

${ }^{29}$ Jeremy Foster, Washed with Sun. Landscape and the Making of White South Africa (Pittsburgh: University of Pittsburgh Press, 2008), 206

${ }^{30}$ Rothman, Resolving Identity-Based Conflict, 9.
}

HoST - Journal of History of Science and Technology 12, pp. 75-105

DOI 10.2478/host-2018-0004 
described in the following steps: ${ }^{31}$

1. Inception: I will illustrate the context and distinguish the reasons behind the conflict (reasons for complaint from both ends of the discussion and how these reasons cause problems to the discussants) and the parties involved (official/trackone diplomats or unofficial/track-two diplomats).

2. Negotiation: I will ascertain the goals sought by each party (who wanted what?), how important those goals were to them, and what kind of power each had to achieve them (what kind of threats or counter-threats could be made).

3. Outcomes: I will take into consideration the options and the urgency of ending the dispute, to analyse whether the chosen option met the goals of the arguing parties.

\section{The geopolitical and technodiplomatic contexts of railway building in Angola and Mozambique}

In Angola, in the aftermath of the Berlin Conference (1884-85), Portugal lost any claims over the region of the Lower Congo and saw its expansion limited in Mid and Higher Zaire. ${ }^{32}$ Later on, Britain made clear to Portugal that in order to stake a claim in Angola, it should occupy the inner regions of the colony with enough forces to keep order, protect the traders and subjugate the native tribes. ${ }^{33}$ So when on 22 July 1885 minister of Marine and Overseas, Pinheiro Chagas, presented a bill to Parliament to build a railway from Luanda to Ambaca, deep in the Angolan countryside, his aim was clear: to impose the Portuguese presence in the region and to set the limits of Portuguese influence in the area. ${ }^{34}$

\footnotetext{
${ }^{31}$ Goncalves, Conflict Resolution, 61-64. Schellenberg, Conflict Resolution, 8, 10-12 and 26-27. Rothman, Resolving Identity-Based Conflict, 19-24; Saaty and Alexander, Conflict Resolution, 5-6 and 15-16. Schellenberg, Conflict Resolution, 32, 69, 71-72 and 98.

${ }^{32}$ Alexandre and Dias, "O Império Africano," 112-114.

${ }^{33}$ Marçal, "Um império projectado pelo 'silvo da locomotiva'," 69, note 187.

${ }^{34}$ Diario da Camara dos Deputados (22 July 1885): 2506.
} 
Shortly after, the government delegated the job to Alexandre Peres, a Portuguese businessman based in Porto, who founded Companhia Real dos Caminhos de Ferro Através de África. ${ }^{35}$ Literally, "Através de África" means "through Africa" and this was indeed the ultimate goal of the enterprise: to build the line from Angola to the eastern coast in Mozambique. British-based The Railway Times described the project as beginning in Angola and ending in Mozambique (the section to Ambaca was just the first step of such a grandiose undertaking). ${ }^{36}$

On the south-eastern coast of Africa, the district of Lourenço Marques (present-day Maputo) had enormous geopolitical relevance. The harbour in Delagoa Bay, besides possessing excellent natural conditions, was not controlled by British interests, unlike those along the more southerly Natal Colony and Cape Colony coasts in South Africa. This was particularly important for the landlocked Transvaal Republic that sought a non-British port to export its gold production and remain independent from British influence. ${ }^{37}$

Naturally, to the United Kingdom the district had an enormous importance Montague George Jessett considered Lourenço Marques the "key to South Africa," which would "insure to us [the British] our proud position as the Paramount Power in South Africa." 38 Previously, in the early 1870s, Britain tried to take the territory from Portugal, but to Lisbon the forfeit of Lourenço Marques (or any other overseas possession) was unthinkable, not only for its economic importance, but also for its symbolism as a token of Portugal's former glory. In 1875, arbitration by French

\footnotetext{
${ }^{35}$ Ângela Guimarães, "Le Chemin de Fer de Luanda a Ambaca," African Economic History 12 (1983): 109-124, on 113-114.

${ }^{36}$ The Railway Times 52/2/2583 (9 July 1887): 59.

${ }^{37}$ Simon E. Katzenellenbogen, South Africa and Southern Mozambique. Labour, railways and trade in the making of a relationship (Manchester: Manchester University Press, 1982), 11-17. For the importance of cross-border railways to landlocked countries, see Michael L. Faye, John W. McArthur, Jeffrey. D. Sachs, and Thomas Snow, "The challenges facing landlocked developing countries," Journal of Human Development 5, no. 1 (2004): 31-69.

${ }^{38}$ Montague George Jessett, The Key to South Africa: Delagoa Bay (London: T. F. Unwin, 1900), 7-8.
}

HoST - Journal of History of Science and Technology 12, pp. 75-105

DOI 10.2478/host-2018-0004 
President McMahon settled the dispute in favour of Portugal. ${ }^{39}$

In this context, a railway connecting Delagoa Bay to the Transvaal had enormous technodiplomatic and symbolic importance: it would reinforce the legitimacy of Portugal in that area of South Africa (besides benefiting from the traffic of the Boer republic) and it would free the Transvaal from the British-controlled rail and harbour system. But to Britain, it would be a threat to its project of becoming a paramount power in that region. After a failed attempt in the second half of the 1870 s to build the line, American contractor Edward McMurdo was hired in 1883 to build the railway. ${ }^{40}$

Further north in Mozambique, in the late 1880s, the province of Manica had been the stage for a territorial dispute between Portugal and Cecil Rhodes' chartered British South Africa Company. ${ }^{41}$ The issue was settled by force, after Britain issued an ultimatum to Portugal in 1890, demanding the removal of Portuguese forces from the areas coveted by Rhodes, to which Portugal surrendered. A treaty signed on 11 June 1891 divided the province between both nations and obliged Portugal to build a railway from Beira harbour to Rhodesia (now Zimbabwe). In the meantime, Portugal conceded the management of Manica to a chartered company of its own (Companhia de Moçambique) that hired two British companies (Beira Railway and Beira Junction) made up by Rhodes' partners to lay down the track. ${ }^{42}$ It took almost ten years to build the line (1892-1900). ${ }^{43}$ During construction and then throughout its operation there

\footnotetext{
${ }^{39}$ António José Telo, Lourenço Marques na Politica Externa Portuguesa (Lisbon: Cosmos, 1991), 31.

${ }^{40}$ Marçal, "Um império projectado pelo 'silvo da locomotiva',” 281-282.

${ }^{41}$ Thomas Pakenham, The Scramble for Africa. White Man's Conquest of the Dark Continent From 1876 to 1912 (New York: Perennial, 2003), 375-387.

${ }^{42}$ Beira Railway was formed to set the track between the border with Rhodesia and Fontesvila, the limit of navigation of the Púnguè River; Beira Junction was entrusted a few years later with the railroad between Beira and Fontesvila. See Anthony H. Croxton, Railways of Zimbabwe. The Story of the Beira, Mashonaland and Rhodesia Railways (London: David \& Charles, 1982), 17 and 26.

${ }^{43}$ Construction included the re-gauging of the whole system from the original 2" gauge to the African standard 3' 6" gauge. See Antony Baxter, The Two Foot Gauge Enigma. Beira Railway, 1890-1900 (Norwich: Plateway Press, 1998), 24-26.
} 
were always reasons for friction between Portugal and Britain. ${ }^{44}$

\section{The inception of the conflict(s)}

In the Angolan railway case, financial issues were at the base of the conflict. However, considering the technodiplomatic relevance and the symbolism of the railroad, soon the conflict took broader proportions.

Companhia Real Através de África raised the capital necessary for construction and operation of the line by issuing $£ 800,000$ in stocks and $£ 1,890,000$ in bonds. ${ }^{45}$ The situation was not uncommon. Usually railway companies preferred raising capital with bonds rather than with stocks. ${ }^{46}$ Nonetheless, the way Companhia Real's bonds were issued raised problems. Whereas the majority of stock capital was with Portuguese investors (associated with the company's board), bonds were issued solely in London, with the intercession of one Count Oksza. ${ }^{47}$ The management of the bonds was entrusted to a committee of trustees. In the loan agreement with the trustees, the company gave the track as collateral; in other words the loan was based on mortgage bonds. ${ }^{48}$ This was usual in Britain, but completely illegal according to Portuguese law:

\footnotetext{
${ }^{44}$ Marçal, "Um império projectado pelo 'silvo da locomotiva'," 330-342.

${ }^{45}$ Portugal, Ministério da Marinha e Ultramar, Caminho de Ferro de Loanda a Ambaca. Relatorio da comissão nomeada por portaria de 15 de junho de 1898 para estudar a situaçao da Companbia Real dos Caminhos de Ferro Atravez de Africa (Lisbon: Imprensa Nacional, 1899), 1-20.

${ }^{46}$ Miguel Artola, "La acción del Estado," in Los ferrocarriles en España. 1844-1943, ed. Miguel Artola, vol. 1, 341-454 (Madrid: Banco de España, 1978), 371-381. François Caron, Histoire des chemins de fer en France (Paris: Fayard, 1997-2005), vol. 2, 37. Hugo Silveira Pereira, "A política ferroviária nacional (1845-1899)" (PhD diss., Universidade do Porto, 2012), 372.

${ }^{47}$ Tadeusz Oksza-Orzechowski, baron and count of Oksza, born in 1838 in Busza, Ukraine, was a medical doctor by training and a diplomat. He served in the Ottoman Empire, in France and in several negotiations with Austria, Poland, and Rome. He set a large network of agents and contacts in different European capitals. In Paris he negotiated several loans and public works contracts for the Sublime Porte (steamers and weaponry), Spain (telegraphs) and Portugal (railways). His ostentatious and lavish manners granted him the unofficial titles of baron and count. According with one of his contacts, "he led one of those mysterious lives that were better left in the shade than to be brought to the light of day." He died, almost completely ruined, in 1902. Stefan Kieniewicz, "Tadeusz OkszaOrzechowski," Internetowy Polski Stownik Biograficzny, www.ipsb.nina.gov.pl/a/biografia/tadeuszorzechowski (accessed April, 14, 2018).

${ }^{48}$ Portugal, Caminho de Ferro de Loanda a Ambaca, 1-20.
}

HoST - Journal of History of Science and Technology 12, pp. 75-105

DOI 10.2478/host-2018-0004 
the railway law of 31 December 1864 clearly stated that any railway built in Portuguese territory belonged to the State; governments could only cede its operation temporarily to private companies that could manage them seeking profit. ${ }^{49}$ In other words, the company could not mortgage the line, as it did not own it. Nonetheless, the Portuguese consul in London vouched for the legality of the deal, which was signed on 12 June 1886.50

This would not be a problem if the railway was financially viable and interest was duly paid to bondholders. However, the construction of the track (1889-1899) cost more than anticipated and the operation of the track was unprofitable.

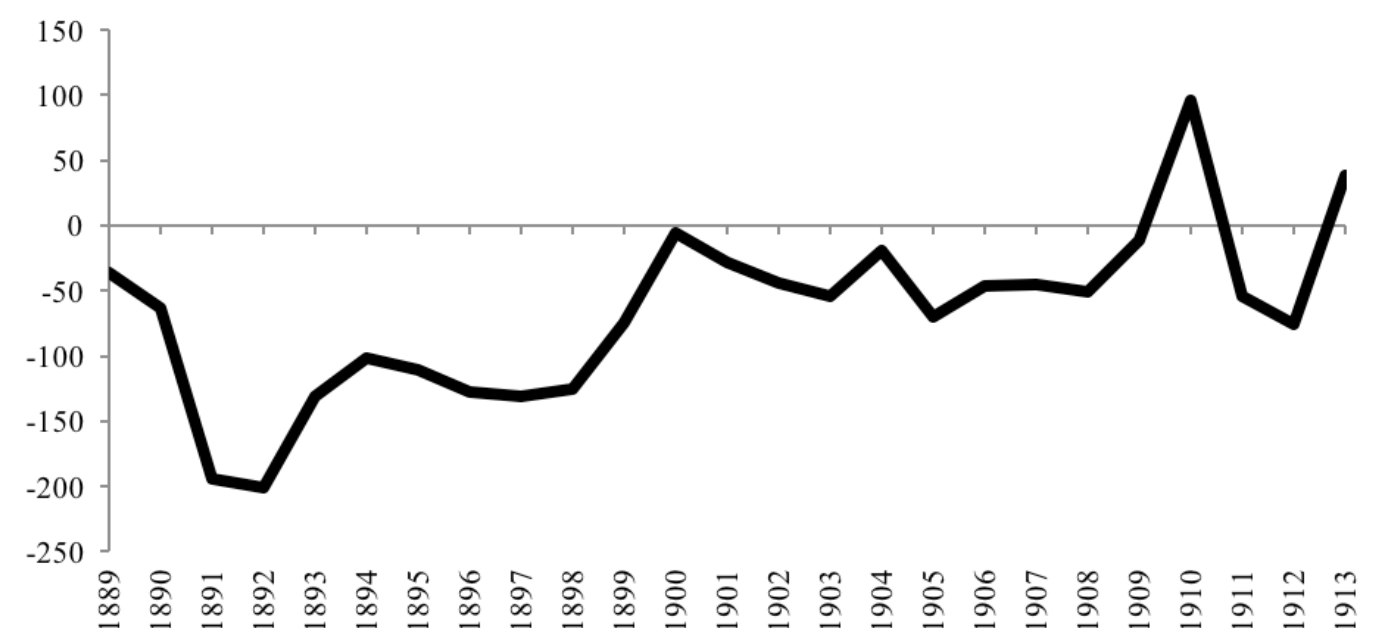

Chart 1 - Net results of Companhia Real Através de África, in contos ( 1 conto $=1,000,000$ reais $\approx £ 222) . .^{51}$

According to the terms of the concession, the government covered the losses and paid a guarantee of yield to the company. ${ }^{52}$ This was not enough to pay the bondholders'

\footnotetext{
${ }^{49}$ Pereira, "A política ferroviária nacional," 329.

${ }^{50}$ Marçal, "Um império projectado pelo ‘silvo da locomotiva', 245.

${ }^{51}$ Caminhos de Ferro de Luanda, pack 299 1H, Arquivo Histórico Ultramarino (hereafter AHU); Miscelânea, pack 2756 1B, AHU.

${ }^{52}$ Portugal, Ministério da Marinha e Ultramar, Legislação e disposiçóes regulamentares sobre caminhos de ferro ultramarinos (Lisbon: Imprensa Nacional, 1908), vol. 1, 152-168.
}

HoST - Journal of History of Science and Technology 12, pp. 75-105

DOI 10.2478/host-2018-0004 
revenues. In 1893, The Railway Times announced that the line could be transferred to the British bondholders if the company failed to meet its obligations. ${ }^{53}$. Even though this was illegal, Portugal's earlier involvement with British entrepreneurs had shown that having the law on its side meant little. ${ }^{54}$ If the entrepreneurs' demands were not met, they would appeal to the Foreign Office and, if successful, it was likely that the London Stock Exchange would then shut its door to Portuguese debt titles. ${ }^{55}$

In any case, all parties had reasons for concern. British investors were on the brink of not getting their money's worth; the Portuguese company was facing bankruptcy; the government in Lisbon was being threatened by a process that might end in losing to British interests a powerful political, economic, and colonizing tool, especially in a strategic and coveted area of Africa. So, although the conflict was apparently between two private parties, the company and the trustees, it did actually involve indirectly the interests of Portugal and Britain, given the technodiplomatic and symbolic importance of the Ambaca railway in Angola.

Conflict in Lourenço Marques was different and more transparent. American contractor McMurdo apparently was an outsider, as he did not possess any connections with

\footnotetext{
${ }^{53}$ The Railway Times 63/7/2876 (18 February 1893): 236.

${ }^{54}$ Previous experiences have major relevance in the outcome of conflict resolution. Goncalves, Conflict Resolution, 61-64. Schellenberg, Conflict Resolution, 32.

${ }^{55} \mathrm{~A}$ classic example occurred with the line from Barreiro to Évora and Beja in mainland Portugal, adjudicated to the South Eastern of Portugal Railway Company, founded and funded by British entrepreneurs and investors. Albeit the contract clearly stated that no debts of the company were guaranteed by the State, Portugal had to reimburse the company of the bonds it issued, as the alternative was the inability to borrow money from the London Stock Exchange. South Eastern Railway; claims of Mr. Mangles and others, FO 63/963, The National Archives (Kew, hereafter TNA). See also Hugo Silveira Pereira, "'A marcha imoderada de um falso progresso': o reformismo, uma impossível alternativa ao fontismo?," História. Revista da FLUP 4, no. 6 (2016): 251-268. Hugo Silveira Pereira, "Markets, Politics and Railways: Portugal, 1852-1873," in Markets and Politics. Private interests and public authority (18th-20th centuries), eds. Christina Agriantoni, Christina Chatziioannou, and Leda Papastefanaki, 223-239 (Volos: Thessaly University Press, 2016). António Lopes Vieira, "A política de especulação: uma introdução aos investimentos britânicos e franceses nos caminhos-de-ferro portugueses," Análise Social 24, no. 101-102 (1988): 723-744.
}

HoST - Journal of History of Science and Technology 12, pp. 75-105

DOI 10.2478/host-2018-0004 
Britain (apart from his supremely Scottish surname), Portugal or Transvaal. ${ }^{56} \mathrm{He}$ was, however, a "concession-hunter" and a speculator, which, in the end, ignited conflict.

The entrepreneur accepted the task of building and operating the railway from Delagoa Bay to the frontier with Transvaal without any financial aid from Portugal, neither an allowance per mile built nor a guarantee of yield. He had, however, liberty to charge the fares he wished during the term of a 99-year contract. ${ }^{57}$ Before the start of construction, McMurdo approached the Transvaal government seeking a through-traffic arrangement, but the proposed fares were considered too high by the Transvaalian government, which impeded an agreement. Afterwards, he proposed leasing the line to Transvaal for an annual rent of $6 \%$ of $£ 925,000$ (total amount of stock and bonds McMurdo expected to raise, although construction cost was estimated at $£ 281,000) .{ }^{58}$ Once again his offer was rebuffed. Later, the contractor formed a new company (Delagoa Bay \& East African Railway Company) based in London. He kept the majority of the shares for himself, and then transferred the railway concession to the Company. ${ }^{59}$

Portugal and Transvaal understood that a railway line managed by McMurdo would not meet their goals and might even act to the benefit of British interests in South Africa; McMurdo seemed determined to charge very high fares, which would divert traffic to other South African railways controlled by British agents. Throughout 1888, the Transvaal government contacted the Portuguese representative, demanding that Portugal either force McMurdo to charge fairer fares or rescind his contract. ${ }^{60}$ British politicians watched the situation. In the House of Commons, between March and May

\footnotetext{
${ }^{56}$ Edward McMurdo, born in Kentucky in 1842, was a former miner and officer of the American armed forces. After the American Civil War, he devoted himself to business speculation with little success but much controversy, as most of his enterprises were bogus or failures. Delagoa Bay Railway Company Correspondence, (letter 13 July 1889), 136-137, FO 403/110, TNA. Delagoa Bay Railway Arbitration, letter 13 February 1892, FO 63/1266, TNA. Marçal, "Um império projectado pelo 'silvo da locomotiva'," 280, note 924.

${ }^{57}$ Portugal, Legislação e disposiçôes regulamentares, vol. 1, 109-120.

${ }^{58}$ Kenneth Wilburn, "McMurdo, Edward," in Historical Dictionary of the British Empire, eds. James Stuart Olson and Robert Shadle, 738-740 (London: Greenwood, 1996).

${ }^{59}$ Katzenellenbogen, South Africa and Southern Mozambique, 19-20. Telo, Lourenço Marques, 49-50.

${ }^{60}$ Delagoa Bay Arbitration, telegrams 20 June 1888, 23 June 1888, FO 63/1263, TNA. Delagoa Bay Railway Arbitration, telegrams 28 June 1888, 14 July 1888, FO 881/6237X, TNA. Telo, Lourenço Marques, 80-84.
}

HoST - Journal of History of Science and Technology 12, pp. 75-105

DOI 10.2478/host-2018-0004 
1888, three parliamentarians, Gourley, Knatchbull-Hugessen and Morgan, asked the government if it was doing anything to control the railway of Lourenço Marquesconsidered by Knatchbull-Hugessen as key to British commerce with the Transvaal. Albeit the government stated that it could do nothing regarding a foreign railway, it was clear that its control was an important matter (and desire) within British political circles. ${ }^{61}$

On 25 June 1889, Portugal decided to rescind the contract with McMurdo, arguing that he had failed to meet the deadline for construction. ${ }^{62}$ Although the contract stipulated that in such circumstances the line should be auctioned and re-leased to the highest bidder, the Portuguese government ignored that obligation. Fearing that McMurdo might make a bid and get the line back, it took immediate possession of the works. ${ }^{63}$ In Britain, the decision was considered "a deed to which the modern history of civilised governments affords no parallel" and its only motivation "the desire on the part of both Portugal and the Transvaal Governments to nullify British influence in Delagoa Bay [Lourenço Marques].”4

Whether Portugal had legal grounds to terminate the contract or not, ${ }^{65}$ the decision opened a conflict between the Portuguese government, the British bondholders and the American stockholders (the heirs of McMurdo who died in May 1889) ${ }^{66}$. British and American investors were naturally unhappy with the confiscation of their investment and demanded compensation. Rapidly, though, the claimants brought to

\footnotetext{
${ }^{61}$ The Railway Times 53/10/2618 (10 March 1888): 329; 53/11/2619 (17 March 1888): 375; 53/20/2628 (19 May 1888): 669.

${ }^{62}$ Portugal, Legislação e disposiçôes regulamentares, vol. 1, 359-365.

${ }^{63}$ Telo, Lourenço Marques, 49-87.

${ }^{64}$ Delagoa Bay Railway Concession, FO 881/8053X, letter 27 June 1889, TNA.

${ }^{65}$ There were breaches of contract from both sides of the agreement. McMurdo had indeed failed to meet the deadline and he had transferred the concession to the new company without authorisation from the Portuguese government. However, Portugal did not state clearly the ending point of the line (it was in the border with the Transvaal, a matter that was under negotiation with the Boer republic) and it had previously conceded a tramway parallel to the railway from Delagoa Bay to Transvaal, which violated the monopoly of rail transport granted to McMurdo in the terms of the contract. Alfredo Pereira de Lima, História dos Caminhos de Ferro de Moçambique (Lourenço Marques: Administração dos Transportes de Moçambique, 1971), 110-150.

${ }^{66}$ Wilburn, "McMurdo, Edward,” 739-740.
}

HoST - Journal of History of Science and Technology 12, pp. 75-105

DOI 10.2478/host-2018-0004 
the dispute the American and British Foreign Offices. ${ }^{67}$ The dispute, which originally was resource-based, soon acquired political and technodiplomatic elements, especially as far as Britain was concerned, considering the relevance of the Lourenço Marques railway to its agenda for South Africa.

In Manica, the conflict was not as visible as in Ambaca and Lourenço Marques/Delagoa Bay. Apparently, the main divergence had been settled with the treaty signed in 1891 . However, the line had been an imposition on Portugal after a humiliating ultimatum by a foreign power. Moreover, partners of Cecil Rhodes (Alfred Beit and Rochfort Maguire) managed the Beira Railway and the British South Africa Company itself ruled Beira Junction. ${ }^{68}$ Finally, construction and operation of the line aggravated the state of underlying friction between the companies involved (the Portuguese chartered Companhia de Moçambique and the railway companies), which threatened to extend to an upper level between Lisbon and London.

Construction was managed fully by British men (the Pauling brothers as contractors, and Alfred Lawley and Charles Metcalfe as chief-engineers). This denied the Portuguese chartered company any supervision. The contract included neither construction details nor penalties for noncompliance. So, the engineers and contractors set the direction they pleased with the features they decided, without consulting the Portuguese chartered company or the Portuguese government. The line was measured in Imperial units (instead of the metric units used in Portugal), rails and rolling stock came from Britain, ${ }^{69}$ new towns were given English names, and the Union Jack flag was unfurled at the stations. The railway company even claimed (falsely) that the land where the rails

\footnotetext{
${ }^{67}$ The Railway Times 57/15/2727 (12 April 1890): 472 and 487.

${ }^{68}$ Croxton, Railways of Zimbabwe, 16-17 and 26.

${ }^{69}$ The Railway Times 73/16/3145 (16 April 1898): 529.
}

HoST - Journal of History of Science and Technology 12, pp. 75-105

DOI 10.2478/host-2018-0004 
and the railway structures were set was British territory. ${ }^{70}$

Englishness did not just prevail during construction. After the line was opened, rules, regulations, and orders were issued in English; the fares were substantially higher than those permitted by the terms of the concession; even the lands neighbouring the line belonged mostly to British citizens; ${ }^{71}$ and the figures of the operation (revenues, costs, passengers and goods carried) were not disclosed to the Portuguese authorities. A Portuguese officer stationed in Manica, Aires de Ornelas, considered the whole situation sombre. In a report to the government, he concluded that the territory was Portuguese in name only and foresaw that it would be tremendously difficult to change that. ${ }^{72}$

Although the construction had cost Portugal nothing (it had even received a small share of stock capital in the Beira Railway Company), and the operation was smooth and was helping the revival of the harbour in Beira (see Chart 2 below), the railway was contributing to a de-nationalization of the region from its original "rulers," the Portuguese chartered Companhia de Moçambique. In this context, it was natural that the Companhia de Moçambique desired stronger control over the line in order to limit British South Africa Company ambitions and at the same time serve the Portuguese agenda for the region.

\footnotetext{
${ }^{70}$ Marçal, "Um império projectado pelo 'silvo da locomotiva'," 320-336. In 1896, general-manager of Companhia de Moçambique, Fontes Pereira de Melo Ganhado, wrote a pleading letter to the government. He claimed that the railway company acted as it pleased, without providing any information to the Portuguese chartered company. Its engineers treated Chimoio (a town in Portuguese territory) as if it were "as British as Umtali [now Mutare]." In sum, it was as if the railway "was being built in a far and away country, instead of being built in the most surveyed region of the Portuguese territory." Copia de documentos officiaes trocados entre a Companhia de Moçambique e o Governo de Sua Magestade de Janeiro a Dezembro de 1896, 4-6.

${ }^{71}$ Bárbara Pinto Teixeira Direito, "Políticas Coloniais de Terras em Moçambique: o caso de Manica e Sofala sob a Companhia de Moçambique" (PhD diss., Universidade de Lisboa, 2013), 130, 145, 194195 and 200.

${ }^{72}$ Aires de Ornelas, "O caminho de ferro da Beira e a passagem das tropas imperiaes inglezas em Julho de 1896," Revista do Exército e da Armada 7 (1896): 257-264, on 264.
} 


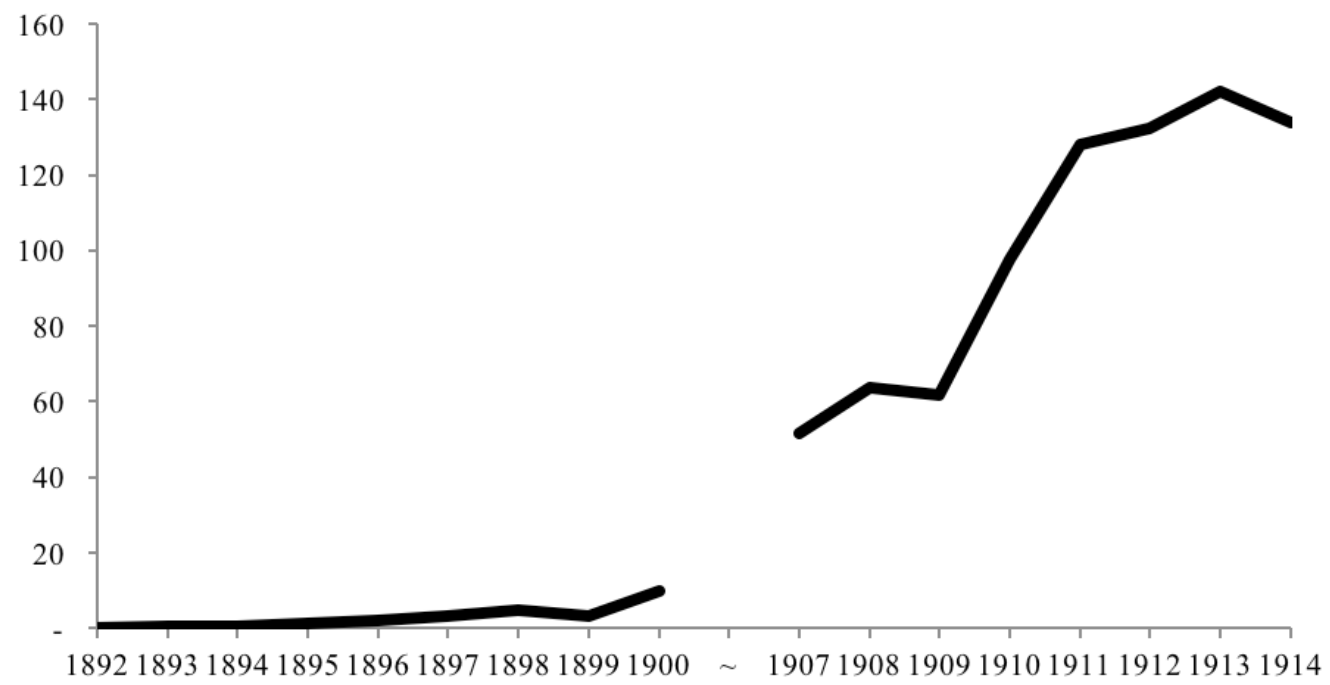

Chart 2 - Commercial movement in the customhouse of Beira (in contos). No data between 1900 and $1907 . .^{73}$

\section{Negotiating a solution}

The three situations of conflict over nominally Portuguese railways in colonial southern Africa had distinct origins, natures, and features. Some escalated quickly (the case of the Lourenço Marques railway), others lingered for years before arriving at a deadlock when an understanding was impossible. Therefore, the contours of the subsequent discussions also presented different characteristics. However, there was one important detail in common to the discussions and disputes: all occurred in the 1890s and early 1900s, a particularly difficult period in Portuguese history.

As mentioned before, the British ultimatum of 1890 was a humiliating event for Portuguese society. It strengthened nationalistic feeling about the colonies and the antagonism towards the British. Thereafter, they were represented as spoilers of valuable

${ }^{73}$ Boletim da Companhia de Moçambique, 1893-1910; Boletim do Governo do Território da Companhia de Moçambique, 1911-1915; Boletins Estatísticos do Movimento Comercial e Marítimo no Território de Manica e Sofala, 1908-1909.

HoST - Journal of History of Science and Technology 12, pp. 75-105

DOI 10.2478/host-2018-0004 
territories of the Portuguese Empire and blamed for a situation that dishonoured Portugal. ${ }^{74}$ Demonizing and blaming opposing parties is common in conflicts, ${ }^{75}$ particularly those that include identity issues, ${ }^{76}$ which can, in the end, strengthen the cohesion of the groups in dispute. ${ }^{77}$

Besides the political challenges created by the ultimatum, Portugal also faced financial difficulties in the 1890s. In 1892, after the government declared a partial default, it abandoned the gold-standard, and struggled to access external financial markets. Settlement with creditors was only agreed upon in $1906 .{ }^{78}$ Albeit indirectly, this climate of financial uncertainty affected the negotiating processes - financial markets have a bearing on conflict resolution. ${ }^{79}$ Besides, it is well known that during negotiations one party is aware of how much the resolution of the conflict will cost its opponent(s). ${ }^{80}$ Considering that the conflicts were also resource-based, these financial challenges left Portugal with little margin for manoeuver.

Negotiations regarding the Ambaca railway were held mainly between the Portuguese company and the Portuguese government, but the looming presence of the bondholders' trustees, and subsequently the British government, and their claim over the property of the line, although illegal, was a constant threat. Thus, the option of just letting the

\footnotetext{
${ }^{74}$ Valentim Alexandre, Origens do Colonialismo Português Moderno (Lisboa: Sá da Costa, 1979), 64.

${ }^{75}$ Vamik D. Volkan, "The Need to Have Enemies and Allies: a Developmental Approach," Political Psychology 6, no. 2 (1985), 219-247.

${ }^{76}$ Rothman, Resolving Identity-Based Conflict, 24 and 39.

${ }^{77}$ Schellenberg, Conflict Resolution, 65-66.

${ }^{78}$ Luís Aguiar Santos, "A crise financeira de 1891: uma tentativa de explicação," Análise Social 36, no. 158-159 (2001): 185-207.

${ }^{79}$ Schellenberg, Conflict Resolution, 74-75.

${ }^{80}$ Saaty and Alexander, Confict Resolution, 10.
}

HoST - Journal of History of Science and Technology 12, pp. 75-105

DOI 10.2478/host-2018-0004 
company go bankrupt, although seductive, was very risky ${ }^{81}$

The conflict was under control as long as the bondholders got their biannual payments in due time. So that became the main goal of the Portuguese government, which always fulfilled the terms of its contract with Companhia Real: the operation losses were covered, and the guarantee of yield duly paid. ${ }^{82}$

However, the amount due to the bondholders was superior to the subsidy paid by the State. The situation worsened after the 1891 default, as the interest had to be paid in pounds sterling, but the guarantee of yield was paid in the devalued Portuguese currency (reais/contos). Companhia Real blamed the State for its situation, arguing that it had suffered severely with the default and claiming that the government should pay the subsidy in sterling (thus covering the losses in the exchange rate). Furthermore, it claimed that the State had not built any roads in Angola, which were to feed the railway with traffic. ${ }^{83}$

In the meantime, different private investors (British, but also German, Dutch, Belgian, and French) observed the situation, hoping to eventually control the railway. In 1898 and 1899, it became known that Germany and Britain were negotiating the division of the colonial territories of bankrupt Portugal. ${ }^{84}$ The company itself used this alleged foreign interest as leverage in the negotiations with the government: in 1911 the board informed the government that it had refused to sell stock to foreign investors out of pure patriotism. ${ }^{85}$ The hint was clear, though. If the government failed to consider the company's needs, the board might decide to sell it to foreign capital.

\footnotetext{
${ }^{81}$ Previous experiences in the Portuguese mainland railways leased to private companies had taught the same lesson. A railway company funded by British or French capital was just too big to fail, in yet another case of private enterprise running on public risk - Daniel Thorner, Investment in Empire, British Railway and Steam Shipping Enterprise in India 1825-1849 (Philadelphia: University of Pennsylvania Press, 1950), 168.

${ }^{82}$ Caminhos de Ferro de Luanda, pack 299 1H, AHU. Miscelânea, pack 2756 1B, AHU.

${ }^{83}$ Guimarães, "Le Chemin de Fer de Luanda," 118-119.

${ }^{84}$ Gisela Guevara, As Relaçôes entre Portugal e a Alemanha em torno de África. Finais do Século XIX e Inícios do Século XX (Lisbon: Ministério dos Negócios Estrangeiros, 2006), 327-336.

${ }^{85}$ Portugal, Ministério das Colónias, Documentos Relativos à Questão de Ambaca (Lisbon: Imprensa Nacional, 1912), 25-27.
} 
Therefore, the Portuguese State gave additional sundry benefits to the railway company: prorogating the deadline for construction, paying the subsidy in advance, acting as guarantor for the company's loans, allowing increases in fares, ${ }^{86}$ and building the extension of the line to the rubber-producing region of Malange. ${ }^{87}$ These constituted a substantial financial effort for the Portuguese Treasury. The alternative of not granting them would mean the default of the company, the complaint of the trustees, and an intervention by the British government, and likely loss of control of the railway to foreign interests.

Additionally, the government appointed an official representative (José de Almada) to meet directly with the trustees in order to alter the terms of the contract, annulling the mortgage of the railway and granting a State guarantee to pay the bonds' interest. ${ }^{88}$ Nothing came out of these talks, as the trustees held the upper hand and they did not need to change the terms of the loan contract. In this process, Portugal followed a negotiation style between compromise (proposing a series of trade-offs) and collaboration (pooling individual needs and goals towards a common objective) ${ }^{89}$

Nonetheless, since the company always paid its due, there were never grounds for a hostile takeover by foreign interests. Regardless, the situation was a powder keg just waiting to explode. Some proposed that the State should cease its aid to the company and simply let it go bankrupt. Others preferred nationalisation of the company. It was argued that with the line under full State control, it would be far from the grasp of foreign interests and would promote Portugal's colonising goals. ${ }^{90}$

Nationalising Companhia Real was not an easy task, however, because the company also blamed the State for its situation and demanded greater compensation than the State was willing to pay. Notwithstanding, Portugal managed to cope with the claims

\footnotetext{
${ }^{86}$ Marçal, "Um império projectado pelo 'silvo da locomotiva', 247.

${ }^{87}$ Portugal, Direcção dos Caminhos de Ferro de Luanda, Monographia do caminho de ferro de Malange (Luanda: Imprensa Nacional, 1909).

${ }^{88}$ Caminho de ferro de Ambaca, room S12, module E14, shelf P02, number 75456, process 32, Arquivo Histórico-Diplomático.

${ }^{89}$ For styles of negotiation, see Goncalves, Conflict Resolution, 48-52.

${ }^{90}$ Marçal, "Um império projectado pelo 'silvo da locomotiva', 256.
}

HoST - Journal of History of Science and Technology 12, pp. 75-105

DOI 10.2478/host-2018-0004 
of the company and the trustees for over 40 years and over several rounds of negotiations and arbitrations. When in 1938 the State and Companhia Real finally settled the nationalisation of the company and the railway, Portugal already had a firm grasp over Angola. The railway was no longer the decisive tool for territorial appropriation that it had been from the 1880 s. ${ }^{91}$

Contrary to what happened in Ambaca, conflict resolution in Lourenço Marques involved the governments of Portugal, Britain and the United States directly. After taking possession of the line (and refusing to auction it), the Portuguese executive tried to settle the dispute within the Portuguese legal framework (arguing that, according to the concession terms, the company was Portuguese for all judicial purposes). Initially, Portugal argued that it was entitled to terminate the contract and confiscate the line. ${ }^{92}$ Later, it offered to reimburse investors the money they had invested..$^{93}$ The ultimate goal, however, was to keep the railway under full State control, so that the government could use it to impose the Portuguese agenda on Lourenço Marques, free from any external influence. Indeed, shortly after the confiscation of the line, Portugal agreed with the Transvaal a through-traffic agreement for goods transported from Lourenço Marques to Pretoria. ${ }^{94}$

Neither the British nor the Americans accepted the offer, as they demanded not only their money back, but also compensation for the future profits they were prevented from receiving. Their respective governments heeded their complaints: London and Washington informed Lisbon that its original offer was unacceptable.

\footnotetext{
${ }^{91}$ Marçal, "Um império projectado pelo 'silvo da locomotiva',” 260-268.

92 The Railway Times 56/23/2709 (7 December 1889): 699.

${ }^{93}$ In parliament, minister of Foreign Affairs, Hintze Ribeiro, stated that Portugal did not seek to profit from somebody else's effort. The government was willing to compensate the investors in "fair terms." Diario da Câmara dos Deputados 21 July 1890: 704.

${ }^{94}$ Correspondence. Delagoa Delagoa Bay Railway; setting up of an Arbitration Tribunal, letter 6 September 1889, DO 119/141, TNA.
} 
The three parties agreed to an independent dispute arbitrator. This limited the ability of a strong party to impose a final decision on a weaker one, but led to competing negotiation where the parties kept an aggressive stance, with little or no regard towards the needs of the other. The parties chose Switzerland from a list of options composed of Belgium, Denmark, The Netherlands, Sweden, and Switzerland. The Swiss Federal Council nominated the referees. ${ }^{95}$ The tribunal agreed that compensation was due, which in itself was a triumph for Portugal, as it was confirmation that nationalization of the line was final. ${ }^{96}$ However, if the Americans were happy with just financial reparation, ${ }^{97}$ the British hoped to take the opportunity to impose compensation so large that Portugal would be forced to allow a stronger British presence in the Portuguese territories of southern Mozambique. ${ }^{98}$ In 1892, in a letter sent to the British Foreign Office, the High Commissioner for South Africa, Henry Brougham Loch, recommended that Britain should intervene to get concessions of railways and/ or customhouses in Lourenço Marques. ${ }^{99}$ Three years later it was Cecil Rhodes, Prime Minister of Cape Colony, who offered raising the necessary funds to buy the territory or the railway. ${ }^{100}$

To determine the amount of compensation, the parties called engineers. In this particular Britain had the advantage, as it had experienced engineers in the region to vouch for the high value of the railway. Engineers Wolf, Pauling, Butler, and Wileman confirmed that: net profits of the Cape and Natal railways had been on the rise since 1885; gold production from the Transvaal's Witwatersrand mines was increasing

\footnotetext{
${ }^{95}$ Delagoa Bay Railway Company. Further Correspondence, 56, letter 6 September 1889, FO 403/148, TNA.

${ }^{96}$ Marçal, "Um império projectado pelo 'silvo da locomotiva', 305.

${ }^{97}$ In April 1890, the American representative in Lisbon informed his Portuguese counterparts that his government could not accept that any foreign government confiscated the property of American citizens without reparation. Portugal, Ministério dos Negócios Estrangeiros, Documentos apresentados às Cortes na sessão legislativa de 1890 pelo ministro e secretário de estado dos Negócios Estrangeiros: Questão do caminho de ferro de Lourenço Marques (Lisbon: Imprensa Nacional, 1890), 37.

${ }^{98}$ R. J. Hammond, Portugal and Africa: 1815-1910 - a study in uneconomic imperialism (Stanford: Stanford University Press, 1996), 245-271.

${ }^{99}$ Delagoa Bay Railway Arbitration, letter 20 November 1892, FO 63/1266, TNA.

${ }^{100}$ Correspondence. Delagoa Delagoa Bay Railway; setting up of an Arbitration Tribunal, letter 2 December 1895, DO 119/141, TNA.
} 
since 1887; the harbour of Lourenço Marques was the natural outlet of Transvaal; the railway was the quicker route from the Transvaal gold fields to Lourenço Marques; probable annual net profit of the railway oscillated between $25 \%$ and $50 \%$ of the cost of construction. ${ }^{101}$

Portuguese engineers in Lisbon countered the opinions of their British colleagues, arguing that they were exaggerated and lacked any justification. However, none of those technicians had experience in Africa. ${ }^{102}$

The Swiss tribunal also sent to South Africa three experts, Stockalper, Dietler, and Nicole, who estimated the cost of the railway as $£ 255,000$ and its overall value $£ 1,820,000$. ${ }^{103}$ The figure was far from the $£ 3,245,000$ demanded by the Americans and British. In 1900, ten years after the arbitration started, the tribunal decided that Portugal had to pay roughly $£ 950,000$ to the British and American creditors. ${ }^{104}$

Trehane, the American representative, was appalled - he could not find the words "to speak in too strong terms of reprobation of the dilatory, careless, and slovenly manner in which the Tribunal has done its work." ${ }^{105}$

The British were more acquiescent, as they realised that the shady dealings of McMurdo had weighed in the final decision. Also, on the brink of war with the Transvaal, the British had got from Portugal the commitment of not transporting weapons and ammunition to the Boer republic. ${ }^{106}$ After the war and the British annexation of the Transvaal, the railway fostered a symbiosis between both colonies' economies, as it conveyed Transvaal

\footnotetext{
${ }^{101}$ Files Relating to the Lourenco Marques Railroad Claim, 1891 - 1900, Mémoire présenté par le Gouvernement des Etats-Unis de l'Amerique du Nord, 215-228, ARC Identifier 1142888, HMS/MLR Entry Number PI 177294 Box 2, National Archives (Washington).

${ }^{102}$ Conselho de Obras Públicas, box 42 (1894), report 24389 (22 October 1894), Arquivo Histórico do Ministério das Obras Públicas.

${ }^{103}$ Delagoa Bay Railway Arbitration, letter 4 May 1898, FO 63/1358, TNA. The Railway Times 73/19/3148 (7 May 1898): 626.

${ }^{104}$ Telo, Lourenço Marques, 163-166.

${ }^{105}$ Correspondence. Delagoa Bay Railway; setting up of an Arbitration Tribunal, letter 2 May 1900, DO $119 / 142$, TNA.

106 Telo, Lourenço Marques, 155-157.
}

HoST - Journal of History of Science and Technology 12, pp. 75-105

DOI 10.2478/host-2018-0004 
gold to Lourenço Marques to be exported, and transported labour from Mozambique to the Witwatersrand goldmines. ${ }^{107}$ This cooperative economic development ${ }^{108}$ helped to heal the wounds of the British-Portuguese conflict in southern Mozambique.

For Portugal, the final decision was not negative (even though it was only expecting to pay the construction costs). Since the confiscation in 1889 Portugal profited $£ 206,502$ from its operation. In the following years until the eve of World War I, the operation paid over $£ 1,500,000$ (see chart 3 below). But more importantly, Portugal retained full ownership of the line.

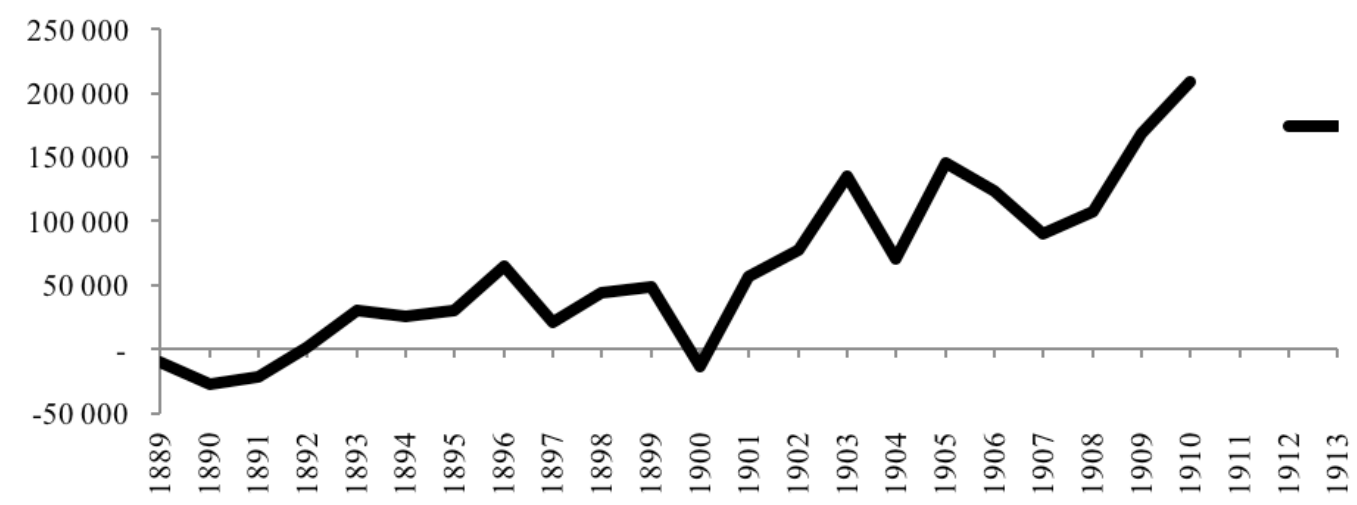

Chart 3 - Net results of the operation of the Lourenço Marques railway, in pounds sterling. No data for 1910 and $1911 .{ }^{109}$

In Beira, conflict was not palpable, but it was latent, as the Portuguese chartered company resented the wide autonomy enjoyed by the railway companies and sought a larger control over the operation, so that it could use the line to promote the nationalization of Manica. Throughout the 1890s, the general-manager of

\footnotetext{
${ }^{107}$ Felizardo Bouene and Maciel Santos, "O modus vivendi entre Moçambique e o Transval (19011909). Um caso de 'imperialismo ferroviário'," Africana Studia 9 (2006): 239-269.

${ }^{108}$ Montville, "The Arrow and the Olive Branch," 7-8 and 16-19.

${ }^{109}$ Questão do Caminho-de-Ferro de Lourenço Marques entre Portugal, E.U.A e Inglaterra, pack 2526 1B, AHU; Miscelânea, pack 2756 1B, AHU.
} 
Companhia de Moçambique, Mr. Ganhado, asked the Portuguese government to intervene and force the railway companies to submit to some control to the Portuguese chartered company, with no practical results. He regretted he got no help at all from the Portuguese ambassador in London. ${ }^{110}$

The railway companies (Beira Railway and Beira Junction), however, were happy with this state of affairs, whereas Portuguese authorities in Lisbon preferred to avoid worsening the conflict. Their reasons were that: (1) the working of the line was contributing to the development of the harbour in Beira; ${ }^{111}$ (2) the enterprise had cost Portugal nothing and it was the only one in the entire Empire that was not draining money from the Portuguese Treasury; ${ }^{112}$ (3) Portugal was already handling two conflicts with Britain, so that creating a new one in Beira would just add fuel to the difficult technodiplomatic relation between both nations; and (4) the government had already obtained from Britain the acknowledgment that with the railway Portugal had met all the conditions imposed in the 1891 Treaty. ${ }^{113}$ This was a situation where direct communication between governments was not worthwhile, and it was advisable that negotiations resumed with track-two agents. ${ }^{114}$

The policy of avoiding conflict in Beira is clear in the following detail: as usual, both Beira Railway and Beira Junction used bonds to raise the capital necessary for the undertaking. Both gave as collateral the line itself, but in neither case did Portugal

\footnotetext{
110 In 1896, Ganhado claimed he had written 41 letters to the government since 1891. Copia de documentos officiaes trocados entre a Companhia de Moçambique e o Governo de Sua Magestade de Janeiro a Dezembro de 1896, 4. Copia de documentos officiaes trocados entre a Companhia de Moçambique e o Governo de Sua Magestade de Janeiro a Dezembro de 1898, 118-119.

${ }^{111}$ Portuguese engineer Joaquim José Machado agreed the railway was facilitating commerce and the overall "civilisation" of Africa - shunning away the opinion according to which Portugal in Africa neither did anything nor did it allow others to do something. Copia de documentos officiaes trocados entre a Companhia de Moçambique e o Governo de Sua Magestade de Janeiro a Dezembro de 1895, 174-178.

112 When, in 1896, Portuguese MP, Mariano de Carvalho, asked the government to explain the situation in Beira, minister João Franco simply replied: "the railway does not cost anything to the Portuguese government." See Diario da Camara dos Deputados 17 March 1896: 685.

${ }^{113}$ Fulfillment of 11 June 1891. Beira Railway, FO 93/77/52, TNA.

114 Stewart, "The Dartmouth Conference," 21-22.
} 
oppose or complain. ${ }^{115}$ Even in the Portuguese parliament - where debates about railways and foreign intervention were usually long and vivid ${ }^{116}$ - the Beiragate was timidly discussed: between 1896 and 1899 there were only seven meetings between government and opposition that, furthermore, ended quite briefly. ${ }^{117}$

There was indeed a feeble attempt to counter the British presence in Manica by attracting Belgian capital to the region. In 1895, Companhia de Moçambique contracted with Belgian engineer Leopold Porcheron for the construction and operation of a new railroad from Beira northwards to the Zambezi River. Porcheron transferred the concession to the Belgian-based Compagnie du Chemin de Fer de Beira au Zambeze. However, nothing would come out of this contract in the following years. ${ }^{118}$

From 1897 onwards, rumours circulated that the railway companies were negotiating the lease of the lines to the firm that operated railroads in Rhodesia (Mashonaland Railway Company, also controlled by British South African Company). ${ }^{119}$ In August 1900, the railway companies informed Companhia de Moçambique that the lease was complete. Once again, the board of the Portuguese chartered company was baffled and kept aside from negotiations. ${ }^{120}$ One year later, the lease agreement was presented to Companhia de Moçambique. Officers at the Portuguese Ministry of Marine and Overseas suggested the new contract was acceptable as it stipulated a decrease in fares and also broader supervision powers by the Portuguese chartered company; additional alterations to the contract should be kept to a minimum, considering the difficulty of

\footnotetext{
115 Beira Railway Company Limited. Counsel's Opinion on Certificate of Incorporation, prospect 28 October 1892, TNA. Company No: 36808; Beira Railway Company Limited. Incorporated in 1892. Dissolved in 1959, prospect 28 October 1892, BT 31/37658/36808, TNA. Company No: 44637; Beira Junction Railway (Port Beira to Fontesville) Limited. Incorporated in 1895. Dissolved between 1933 and 1948, BT 31/31400/44637, TNA.

116 Pereira, "A política ferroviária nacional," annex 18.

117 Diario da Camara dos Deputados 1896-1899.

118 Marçal, "Um império projectado pelo 'silvo da locomotiva'," 348-349.

119 Copia de documentos officiaes trocados entre a Companhia de Moçambique e o Governo de Sua Magestade de Janeiro a Dezembro de 1897, 249.

${ }^{120}$ Copia de documentos officiaes trocados entre a Companhia de Moçambique e o Governo de Sua Magestade de Janeiro a Dezembro de 1900, 326-327 and 481-482.
}

HoST - Journal of History of Science and Technology 12, pp. 75-105

DOI 10.2478/host-2018-0004 
negotiating with the railway companies. ${ }^{121}$

In the next few years, the feud followed mostly economic and business contours, involving fares and the development of the harbour in Beira, in order to attract a large chunk of Rhodesian traffic. In 1906-1907 a new agreement was reached between the Portuguese chartered company and the companies that operated the Beira railway. It stipulated a decrease in fares and the construction of a new dock in Beira, ${ }^{122}$ which then led to an increase in traffic towards Beira (see chart 2). ${ }^{123}$ As in Lourenço Marques, economic development in the aftermath of the negotiation helped to settle the dispute. But in this case, track-two action also created an ambiance for a more peaceful settlement and a more stable aftermath. ${ }^{124}$

In the end, Portugal was not able to eliminate the British presence and pre-eminence in the railway and in Manica - which led to a new, unsuccessful attempt to attract Belgian capital to build the railway from Beira to the Zambezi River. ${ }^{125}$ However, the railway became responsible for the increase of movement in Beira. Portugal could thus prove to Europe that it was indeed working to colonise, "civilise," and bring "progress" to that area of Africa and thus could still be considered a colonial nation.

\section{Conflict outcomes}

The three conflict cases had different natures, but they cannot be separated from the context of the scramble for Africa in the 1880s and the specificity of the 1890s in the

${ }^{121}$ Caminho-de-ferro da Beira. 1895, 1901, 1903, 1905 a 1908, report 3 June 1901; letter 24 July 1901, pack 2550 1B, AHU.

${ }^{122}$ Portugal, Ministério dos Negócios Estrangeiros, Documentos relativos aos caminhos de ferro da Beira (Lisboa: Imprensa Nacional, 1948), 10-21.

123 Correspondence from 1906. Portugal. Code 436 Files 1079 - 4001, report 21 August 1906, FO 367/17, TNA.

${ }^{124}$ Landrum Bolling, "Strengths and Weaknesses of Track Two: a Personal Account," in Conflict Resolution: Track Two Diplomacy, eds. John W. McDonald Jr and Diane B. Bendahmane, 53-64 (Washington: Foreign Service Institute, 1987), 53-56.

${ }^{125}$ Which, in the end, was built by British capital. Marçal, "Um império projectado pelo 'silvo da locomotiva,", 359-362.

HoST - Journal of History of Science and Technology 12, pp. 75-105

DOI 10.2478/host-2018-0004 
history of Portugal. Also, they illustrate the importance of technology as a "tool of empire" to assert dominance in the colonial landscapes but also the importance of money in the implementation, development (and failure) of technical systems.

Within these contexts, it is clear that despite the graveness of the situation, its settling was not urgent. All three disputes took years to resolve. Evidently, the parties could tolerate a longer situation of conflict, especially in Ambaca (where the conflict was controlled as long as the trustees were paid their due).

Second, throughout these processes, the agency of track-two diplomats was vital during negotiation and settlement. This confirms that track-two diplomacy is not a surrogate for track-one diplomacy, but a supplement. ${ }^{126}$ Their action was visible in the case of the Ambaca and Beira lines, particularly in the latter. In Lourenço Marques, the question was handled directly at a governmental level.

Third, the final results of the negotiations were just one of many possibilities for settling the disputes: Portugal could decide to allow the Ambaca company to go bankrupt; Britain could force the re-leasing of the Lourenço Marques road to another British company, threatening with a closure of the London Stock Exchange to Portuguese bonds; Beira railway companies could utterly refuse any meddling of the Portuguese chartered company and use the track solely for its own agenda.

Fourth, even though the ultimate goals of Portugal and Britain were not achieved (as they were quite opposing), the final results of the negotiations led to a situation where both countries' agendas were favoured. Portugal did not lose complete control of the railways, which were used to foster its colonial economies and to assert the Portuguese presence in Africa. Britain, on the other hand, kept a presence in the Portuguese colonies, exerting a form of informal imperialism. The three conflicts did not lead to a final situation of frustration or violence, but they did not foster development and dynamism ${ }^{127}$ in the relationship between Portugal and Britain in Africa. Rather, they

\footnotetext{
${ }^{126}$ McDonald Jr, "Introduction."

127 See Rothman, Resolving Identity-Based Conflict, 5-6.
}

HoST - Journal of History of Science and Technology 12, pp. 75-105

DOI 10.2478/host-2018-0004 
contributed to the adaptation ${ }^{128}$ of both nations to a new situation of coexistence.

Finally, my analysis also illustrates the importance of the methodology of conflict resolution to History of Technology. In different contexts, the implementation of technical systems was not symbiotic, but rather antagonistic and led to some sort of conflict. Conflict resolution allows a more assertive examination of those processes. Specifically, for those technologies that involved different countries or administrations, conflict resolution was often transferred from official representatives to unofficial agents (track-two diplomats), some of them wielding the power of money. This paper also highlights the importance of these agents who had no diplomatic power, but were crucial for the financial support of the implementation, development and use of technical systems.

${ }^{128}$ See Goncalves, Conflict Resolution, 2.

HoST - Journal of History of Science and Technology 12, pp. 75-105

DOI 10.2478/host-2018-0004 